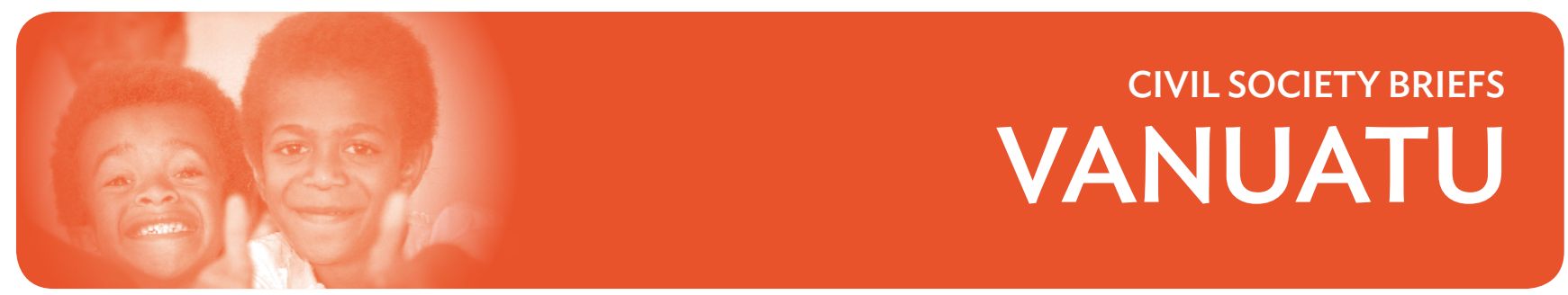

\section{Country and Government Context}

The Republic of Vanuatu is an archipelagic nation comprising 83 islands, of which approximately 65 are inhabited. It is located in the Southwest Pacific Ocean, directly west of Fiji. The islands are spread over 1,000 kilometers in a north-south direction. There are approximately 13 larger islands, including Efate which hosts the capital, Port Vila. The other major urban center is Luganville on Espiritu Santo. The country has six administrative provinces. The country's topography is marked by forested low mountain ranges, including several active volcanoes and narrow strips of coastal land.

With a population of approximately 270,000 , the country is $98 \%$ Melanesian. ${ }^{a}$ The indigenous population is called ni-Vanuatu. With over 110 indigenous languages and many more dialects, it is one of the most culturally diverse nations in the world. There are three national languages: Bislama (pidgin), French, and English. Eighty-seven percent of the population is Christian, with 70\% Protestant. $^{b}$ Approximately $80 \%$ of the population lives in rural areas, although there is an increasing population drift to urban centers. ${ }^{c}$ The currency is the vatu $(\mathrm{Vt})$.

Vanuatu was first inhabited by Melanesians around $550 \mathrm{BC}$ and was unified under Chief Roymata in 1200. First contact with Europeans occurred early in the 17th century with visiting Portuguese explorers. Captain Cook named the islands the New Hebrides in 1774. The first missionaries arrived in Vanuatu in 1839 but did not survive. Anglican missionaries arrived at the islands in the 1860s and Catholic missionaries arrived some 20 years later. A joint naval commission was established by the French and British in 1887 and in 1906 the joint British-French administration of the New Hebrides was established, known as the Condominium. The joint administration led to separate systems for justice, education, and health, along with currencies.

During the 1960 s ni-Vanuatu began to press for independence from the joint administration. Vanuatu gained independence on 30 July 1980. Vanuatu today is a unicameral parliamentary democracy, with a 52seat parliament and multimember electorates. The proliferation of political parties has led to an unstable political landscape with 13 changes of government from 1992 to 2004, ${ }^{\text {d }}$ and four prime ministers between national elections in October 2012 and the most

continued on next page

\section{Civil Society: An Overview}

Important concepts for understanding civil society in Vanuatu are wantok, "big man," and kastom. Wantok are the ties that bind kinship, language, and clan groups, and these ties can cut across organizational and political groups, including civil society. ${ }^{1}$

Wantok ensures a high level of community participation and social protection, but it also creates reciprocity and obligations between kin. The related concept of "big men" is also important in Vanuatu, which ties in with the chiefly system and those who can earn power and status by working for the community. ${ }^{2}$ Chiefly systems are informed by kastom, which is often understood as "tradition," "custom" or "customary law" and in some cases is often used as a metronym for the "chiefly system."” Kastom is a fluid concept that is specific to place, and embodies the distinctiveness of different groups. ${ }^{4}$

Although the chiefly system in Vanuatu is an early form of civil society, the institution of chief can be thought of as a relatively modern invention, arising out of the intersection of indigenous politics, colonialism, and missionization. ${ }^{5}$ Indeed, the word "chief" is not a word used in Vanuatu until it was used in English. ${ }^{6}$ In Vanuatu, a nakamal is a community of related households headed by a chief, 7 and is synonymous with a forum for open discussion and debate, where inclusive community decisions are taken. ${ }^{8}$ The attainment of chief status occurs in different ways in different parts of Vanuatu: in the central and southern areas the status was hereditary or titles were bestowed on certain men, but the northern area of Vanuatu, chiefs earned their titles through accruing respect and through a series of rituals, thus accruing graded status, particularly around pig killing. ${ }^{9}$ While chiefs are seen today to be protectors of kastom, or traditional beliefs, the concept of chiefs was cemented by the church and joint British-French administration as a way of providing traditional representation for local communities to interact with outsiders.

In addition to the chiefly system, many of the earliest civil society organizations (CSOs) in the Pacific were established by missionaries, who, in addition to their religious roles, formed youth and women's groups..$^{10}$ The Presbyterian Church of New Hebrides began in Vanuatu in the 1800s under a mission established by the Presbyterian Church of Canada. An example of the women's groups set up by churches is the Anglican Church of Melanesia Mothers Union, which was established in Vanuatu in

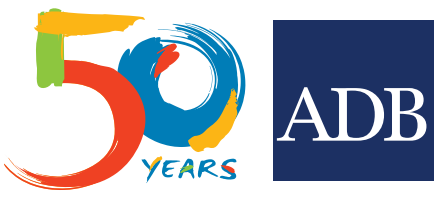


recent election in January 2016. The chief of state is the President, His Excellency Reverend Womtelo Baldwin Lonsdale. The head of government is the Prime Minister Charlot Salwai.

Vanuatu is one of the stronger economies in the Pacific. Its economy is driven by tourism, construction, and aid inflows. The economy has seen steady growth since 2004 , with a long-term average gross domestic product growth of 3\% over 2008-2013. Cyclone Pam, a Category 5 cyclone, hit the country in March 2015, killing 11 and displacing over 76,000 people. The country's infrastructure was severely damaged and it has had a shortterm impact on inbound tourism, with the economy contracting over 2015. Economic growth is expected to rebound in 2016 to $4.5 \%{ }^{\mathrm{h}}$ While the urban economy is dependent on tourism and construction, the rural economy is primarily based on subsistence farming.

Vanuatu's challenges include political instability, severe weather events, and poor transport infrastructure serving a largely rural and dispersed population. Vanuatu is ranked as number one out of 171 countries on the World Risk Report, facing the highest risk of a natural disaster.' Vanuatu's Human Development Index was 0.594 in 2014, placing it in the medium human development group and ranking it 134 out of 188 countries. $^{k}$

The Asian Development Bank (ADB) has worked with Vanuatu since 1981 and has disbursed $\$ 52.2$ million in cumulative disbursements since that time.' A breakdown of disbursements by loan or technical assistance is provided in the brief

aDB. 2015. Basic Statistics 2015. Manila.

b Government of Australia, Department of Foreign Affairs and Trade. 2011. Stretem Rod Blong Jastis: Vanuatu Law and Justice Design Document. http:// dfat.gov.au/about-us/publications/Documents/stretem-rod-blong-jastisdesign-document.pdf

ADB. 2009. Country Partnership Strategy: Vanuatu, 2010-2014. Manila.

d Footnote c.

e Government of Australia, Department of Foreign Affairs and Trade. Vanuatu Country Brief. http://dfat.gov.au/geo/vanuatu/pages/vanuatu-country-brief. aspx

ADB. 2014. Country Operations Business Plan: Vanuatu, 2015-2017. Manila.

g ADB. Vanuatu: Economy. http://www.adb.org/countries/vanuatu/economy

${ }^{\mathrm{h}}$ Footnote g

Footnotec

Alliance Development Works. 2014. World Risk Report 2014. Berlin.

k United Nations Development Programme. 2015. Human Development Report 2015-Work for Human Development. UNDP: New York.

ADB. 2016. Vanuatu Fact Sheet. Manila

1938 in Pentecost Island. ${ }^{11}$ In Vanuatu, the churches have been providers of services in health and education to the mainly rural population since the late 19 th century. ${ }^{12}$

After the missionaries and churches, other European CSOs began to establish during the joint British-French administration. The Scouts have been in Vanuatu since 1956. Reflecting the dual administration preindependence, there were two scouting groups-one French and one English, which merged in 1999. The Rotary Club of Port Vila was chartered in 1972, with a primarily French membership, while the Kiwanis started in Vanuatu in the mid-1970s.

The Vanuatu National Council of Chiefs, later to be the Malvatumauri Vanuatu National Council of Chiefs, was formed in 1977, in the lead up to independence. ${ }^{13}$ Its primary role is to maintain elements of kastom in Vanuatu.
Postindependence, many civil society organizations in Vanuatu were initially established as locally based offices of international nongovernment organizations (NGOs). For example, the Red Cross in Vanuatu first began operating as a division of the British Red Cross, and the Vanuatu Red Cross Society was founded in 1982. World Vision has had an office in Vanuatu since 1983. Foundation of the Peoples of the South Pacific Vanuatu was established in 1988 and then a fully independent local body of the foundation was established in 1997. It is a member-based organization with a focus on good governance, heath, disaster risk management, community capacity building, youth, and natural resource management. The Vanuatu office of Live and Learn was established in 2001. Live and Learn Vanuatu engages in a range of community development programs including sustainable management, biodiversity, environmental governance, and climate change. The Vanuatu Society for Disabled People started as a part of the Red Cross in 1986 but became a separate organization in the late 1980s, called the Nakato Society Blong Vanuatu. It changed its name to Vanuatu Society for Disabled People in 1991. The Adventist Development Relief Agency Vanuatu office has been working in Vanuatu since 2008.

Locally based NGOs also formed postindependence, Wan Smol Bag Theatre Group, which started in 1989 , is an NGO that works in the areas of education, governance, and health. The Vanuatu Family Health Association was founded in 1991 and focuses on the reproductive health of women and men. The Vanuatu Rural Development and Training Centres Association was established in 1992 under the auspices of the Foundation of the Peoples of the South Pacific. It is now independent and is a network of vocational-based schools for young people out of the formal education system. Vanuatu Women's Centre was also established in 1992 as a crisis center for women and children. It has an extensive committee network around the country. Transparency Vanuatu was established in 2001 as a registered charitable organization with the aim of combating corruption and promoting good governance.

Today, there are a range of CSOs in Vanuatu, both formal and informal. At the village level, there are unincorporated associations formed by the community for the purposes of sport, agriculture, and pursuit of religion. ${ }^{14}$ These unregistered groups are usually women's groups, youth groups, or other community governance groups established for a specific purpose (such as a water supply committee). ${ }^{15}$ The more structured or formalized groups include NGOs (registered as charitable associations), churches, trade unions, or foreign organizations given approval to operate in Vanuatu. In 2016, there were 126 organizations registered in the NGO Desk, which was set up under the Ministry of Internal Affairs in the same year. ${ }^{16}$ These operate in a range of sectors including governance; legal services; disaster risk reduction; 
child and maternal health; general health; and dental, housing, and disability services.

Outside the urban centers, the state reach is very weak and power is vested in the churches and kastom chiefly system. ${ }^{17}$ The concept of a nation state is weak, as most identify with their clans and land-based groups. At the rural level, the churches and customary institutions are seen as having legitimacy and relevance to the community, while the state structures outside the capital are perceived as ineffective and artificial. ${ }^{18}$ The only contact that most ni-Vanuatu has with the state outside of the capital is health clinics and primary schools.

The churches, as the most effective grassroots organizations in Vanuatu, are active at the community or household level but less so at a national level. There is also a sense of competition among churches. ${ }^{19}$ At the household or community level they are active in providing services in water and sanitation, vocational training, education, and health. They are active in educating the population on urbanization, the misuse of kava and other drugs, and on HIV/AIDS. ${ }^{20}$ The Vanuatu Council of Churches, the umbrella group for the churches, is seen by some as socially conservative and relatively inactive over issues of national concern, preferring to focus on its traditional base and managing the "competition" from new evangelical churches. ${ }^{21}$

There are trade unions in Vanuatu and they are united under the Vanuatu Council of Trade Unions, which was registered in 2008. The most active are the Vanuatu Teachers Union and the Vanuatu National Workers Union, the latter of which has been a critical commentator on the government's tax agreements and Melanesian Spearhead Group trade agreements. ${ }^{22}$

Radio is the prime form of media in Vanuatu. ${ }^{23}$ The churches own several media outlets including Radio 90 LAEF FM. Internet use is low, but mobile phone penetration is high with $76 \%$ of households owning a mobile phone in 2009. ${ }^{24}$ Media Association Blong Vanuatu, established in 2006, is the local media workers' association. ${ }^{25}$ Facebook and social media is emerging in Vanuatu; the Yumi Tok Tok Stret is a Facebook site that has developed as a forum where ni-Vanuatu can discuss pressing social, political, and economic issues, sometimes with direct interaction between politicians and the constituency. It has a membership of over 12,000 representing approximately $5 \%$ of the population. ${ }^{26}$

\section{Key Civil Society Organizations in Vanuatu}

\section{Church-based Organizations}

- Adventist Development Relief Agency: adra.org.vu E-mail: info@adra.org.vu Tel: +678 25500
- Anglican Church of Melanesia: P.O. Box 162, Port Vila, Vanuatu Tel: + 67823599 or +678 26107

- Caritas Australia: http://www.caritas.org.au/learn/ countries/vanuatu Presbyterian Church of Vanuatu http://pcv.vu/ index.html E-mail: http://pcv.vu/index.html Tel: +67827184

- Vanuatu Christian Council, P.O. Box 3316, Port Vila, Vanuatu. Tel: (678) 27300 or (678) 27303

- Vanuatu Council of Trade Unions, P.O. Box 287, Port Vila, Vanuatu, Tel: (678) 23679

\section{Local Nongovernment Organizations}

- Disability Promotion \& Advocacy Association http://www.dpavanuatu.org/E-mail: dpasanto@ vanuatu.com.vu Tel: +678 37997

- Foundation of the Peoples of the South Pacific Vanuatu: http://www.fspi.org.fj/index.php/ network-partners/fspv E-mail: coralgarden@gmail. com Tel: + 67822915

- Live and Learn Environmental Education Vanuatu: E-mail: vanuatu@livelearn.org Tel: +678 27448

- Transparency Vanuatu: http://www. transparencyvanuatu.org/E-mail: transparency@ vanuatu.com.vu Tel: +678 25715

- Vanuatu Family Health Association: https://vfha15. wordpress.com/E-mail: vfha@vanuatu.com.vu Tel: $+67822140$

- Vanuatu Red Cross Society: http://www. vanuaturedcross.org/E-mail: redcross@vanuatu. com.vu Tel: +67827418

- Vanuatu Rural Development and Training Centers Association: P.O. Box 925, Port Vila, Vanuatu, Tel: $+67827740$

- Vanuatu Society for Disabled People: http:// vanuatusocietyfordisabledpeople.org/ Tel: +678 5522321

- Vanuatu Women's Centre: vwnc@vanuatu.vu Tel: +67825764

- Wan Smol Bag Theatre Group: http://visit. wansmolbag.org/+678 27119

\section{International Nongovernment Organizations}

- Oxfam International: https://www.oxfam.org.au/ country/vanuatu/ P.O. Box 307, Port Vila, Vanuatu Tel: +678 25786

- Save The Children Fund; P.O. Box 283, Port Vila, Vanuatu Tel: 67822794

- UNICEF: Tel: +678 24655

- World Vision: P.O. Box 247, Port Vila, Vanuatu Tel: 67822161

\section{Government-Civil Society Relations}

Since 2002, the Government of Vanuatu has prioritized its commitment to engage with civil society in the process of policy development. This has been 
articulated in the country's national development plans, stating that a priority is to enable "greater stakeholder participation in policy formulation by institutionalizing the role of chiefs, NGOs, and civil society in decision making at all levels of government."27 Despite these statements, civil society participation in government policy-making has been limited, and the opportunities that are available have been underutilized. ${ }^{28}$ Traditionally, civil society in Vanuatu has not fulfilled an advocacy or watchdog role, focusing more on service delivery. ${ }^{29}$ The culture of wantok and reciprocal obligation of clan and kin can impact on the ability of CSO staff to speak out against wrongdoing. ${ }^{30}$ Some argue also that government has generally ignored civil society when it has fulfilled this watchdog role. ${ }^{31}$

While the Malvatumauri, the National Council of Chiefs, has a constitutional right to be consulted in relation to any bill before Parliament, particularly in relation to matters of tradition or custom, the government has resisted engaging the chiefs, and the Malvatumauri's capacity to engage in debate is constrained. ${ }^{32}$ However, there have been occasions where the chiefs have engaged in policy debate, particularly to uphold the conservative leanings of ni-Vanuatu. For 11 years the Malvatumauri and some politicians blocked the passage of the Family Protection Act (designed to give legal protection to women against violence). It was finally passed into law in 2009 after an appeal against the law by the Vanuatu Christian Council was overruled by the Supreme Court. ${ }^{33}$ More recently, the Vanuatu Police Force and the Malvatumauri have been working together under an Australian government-funded program. ${ }^{34}$

Other sectors of civil society also work directly with government. Several churches have memorandums of understanding (MOUs) with government agencies to deliver services in education and health. In 2004 the Vanuatu Association of NGOs (VANGO) signed an MOU with the government to create a partnership and provide accountability for government funds, ${ }^{35}$ although the available avenues for consultation with the government are limited..$^{36}$ Live and Learn Vanuatu has partnership agreements or MOUs with various government departments to implement projects in health, education, climate change, and agriculture. ${ }^{37}$ The Electoral Commission has worked with WanSmolbag and Transparency Vanuatu on civic education and the Media Association of Vanuatu worked with the government to develop policy around right to information..$^{38}$ Several NGO networks, including the Vanuatu Humanitarian Team and the Vanuatu Climate Action Network work closely with government on disaster response and preparedness and climate change. ${ }^{39}$

Despite these instances of cooperation, some have described the relationship between the government and NGOs as distrustful, ${ }^{40}$ "fractious," ${ }^{41}$ and "somewhat strained." ${ }^{42}$ Cyclone Pam, which struck the country in March 2015, saw a major role for many local and international NGOs in the reconstruction effort. However, the government criticized these civil society groups for being preoccupied with visibility and for a failure to work through government channels. ${ }^{43}$ In addition, there have been reports that the government would prefer greater transparency from the churches and NGOs on their programs and activities, with frustration expressed around a lack of information flow from civil society to government about their activities. ${ }^{44}$

Government corruption is an issue that has engaged civil society. The National Council of Chiefs, the National Council of Women, youth groups, and other civil society groups recently joined together to call for the legal process to be allowed to progress, following the charging of 14 ministers of Parliament with bribery. ${ }^{45}$

\section{The Legal Framework for Civil Society}

CSOs are not required to be registered in Vanuatu but freedom of association is provided for under the Constitution. ${ }^{46}$ Most NGOs are registered under the Charitable Associations Act, but can also be unincorporated associations or registered as a company limited by guarantee. The Red Cross, religious bodies, and trade unions register under separate acts. Foreign NGOs may operate within Vanuatu under the express permission of the Ministry for Foreign Affairs, under an MOU with the government. The Vanuatu Financial Services Commission holds a register of all NGOs registered under the Charitable Associations Act, although there is no central register of other CSOs. ${ }^{47}$ The fees for applying to incorporate an NGO under the Charitable Associations Act is Vt5,000 (\$50) and to receive a certificate of incorporation is another Vt5,000 (\$50). ${ }^{48}$ Vanuatu does not tax income or capital gains, so the value-added tax is the main tax that affects CSOs: generally value-added tax is not applied to the supply of goods or services by a nonprofit organization.

\section{Umbrella and Coordinating Bodies}

VANGO or Vanuatu Association of NGOs is the umbrella group for NGOs in the country. It was formed in 1991 and had 126 registered members in $2016 .{ }^{49}$ However, it has suffered from a decline relating to poor governance and was revived in December 2013. ${ }^{50}$ VANGO is an active member of the Pacific Islands Association of Non-Governmental Organisations, a regional umbrella organization which aims to build the capacity of civil society in the Pacific.

\section{Contact details:}

Vanuatu Association of NGOs

Interim chief executive officer: Charlie Timpoloa

Harrison

VANGO Secretariat 


\section{PMB 9096}

Rue D’Auvergne, No. 2 Area

Port Vila

Republic of Vanuatu

Telephone: (678) 26034 (w) / 5958237 (m)

E-mail: vango@piango.net

vangosec@gmail.com

The Vanuatu Nation Council of Women, established in 1980 , is the umbrella group for women's organizations in Vanuatu.

\section{Contact details:}

Vanuatu National Council of Women

P.O. Box 975

Port Vila, Vanuatu

Tel: +67823108

E-mail:vncw@vanuatu.com.vu

The Vanuatu Council of Trade Unions was established in 2008.

\author{
Contact details: \\ Vanuatu Council of Trade Unions \\ Port Vila, Vanuatu \\ Tel: +67823679 \\ E-mail: leba@vanuatu.com.vu
}

The Vanuatu National Youth Council is the umbrella group for youth organizations in Vanuatu.

\author{
Contact details: \\ Vanuatu National Youth Council \\ Private Mail Bag 9043 \\ Port Vila \\ Vanuatu \\ President: Vira Taivakalo \\ E-mail: vanuatu.nationalyouthcouncil@gmail.com
}

The umbrella group for Disabled People's Organizations in Vanuatu is the Disability Promotion \& Advocacy Association. It has 18 affiliates throughout Vanuatu and was established in 2002.

Contact details:

Disability Promotion \& Advocacy Association SANMA Rural Women's Resource Centre

Room 3, SANMA Provincial Headquarters

Luganville, Espiritu Santo, Vanuatu

Tel: +67837997

Mob: +6787796946

Fax: +67837997

E-mail:dpasanto@vanuatu.com.vu

\section{Civil Society Capacity}

The Government of Australia, the Government of the People's Republic of China, and the Government of New Zealand are the major bilateral international aid donors to Vanuatu. Meanwhile, ADB, the European Union, the United Nations agencies, and the World Bank Group are the major multilateral donors. Most donor funds are external; very little government or local CSO funding is available. However, some local CSOs do generate small returns from rental, fundraising, and sales of products. ${ }^{51}$

The churches have received support from the Government of Australia through the Vanuatu Church Partnerships Program under the Vanuatu Christian Council. The six churches in the partnership are the Anglican Church of Melanesia, the Presbyterian Church, the Apostolic Church of Vanuatu, the Assemblies of God Vanuatu, the Churches of Christ Conference in Vanuatu, and the Seventh Day Adventist Church. They work with NGOs Act for Peace, Adventist Development Relief Agency, the Anglican Board of Mission, Transformation Aid International, and Uniting World. The partnership began in 2009 and is now focused on projects in disaster risk reduction, health, and education. ${ }^{52}$ The ties of wantok ensure that volunteerism is high in Vanuatu. The community and human resources available to local community groups to participate in community fora and committees is generally strong.

While most internationally funded CSOs have a range of donors, it is not uncommon for CSOs to become dependent on funds from one particular donor, making them vulnerable to changes in donor funding preferences. ${ }^{53}$ Competition among CSOs for donor funding is high, which leads to a lack of information sharing between organizations and some CSOs seeking funding outside their mandate. ${ }^{54}$

Challenges faced by civil society in Vanuatu include lack of core donor funding: many CSOs rely on funding on a project by project basis and thus limit their sustainability. ${ }^{55}$ Other challenges include lack of qualified staff, ${ }^{56}$ lack of financial sustainability, and limited access to training. ${ }^{57}$ The short-term nature of donor funding and the limited human resource capacity generally makes attracting and retaining skilled staff a major barrier for the civil society sector, as it struggles to offer salaries to compete with international organizations and the private sector. ${ }^{58}$ Some CSOs find donors' technical documentation requirements challenging. ${ }^{59}$

Civil society has low levels of transparency and reporting of their activities in Vanuatu. While international NGOs generally produce annual reports and financial statements online, this is generally not the case for local organizations. Many organizations do not have websites, attributable to low levels of internet access in Vanuatu and a lack of skilled staff to create and maintain organizational websites. ${ }^{60}$

The transportation and infrastructure challenges facing the country with a dispersed rural population also affects the civil society sector. Most CSO leadership and 
structured civil society are based in Port Vila. There has been reported limited sharing of information across civil society, and some mistrust and personality conflicts between NGO leaderships. ${ }^{61}$ The linkages among civil society groups has generally been weak, sometimes prevented by different church or clan affiliations, or the Francophone-Anglophone language divide. ${ }^{62}$

Nevertheless, civil society has come together to pursue common causes. For example, a group of NGOs jointly submitted to the United Nations Universal Periodic Review of Vanuatu in 2008. In addition, a group of 20 CSOs established the Vanuatu Climate Adaption Network and in 2011 the Vanuatu Humanitarian Team, an alliance of NGOs concerned with disaster preparedness, was formed. Both of these alliances have representatives on the national advisory board.

\section{ADB-Civil Society Cooperation in Vanuatu}

The ADB has been working with Vanuatu since 1981 and since that time it has approved 14 loans for $\$ 89.36$ million, 9 grants totaling $\$ 66.74$ million, and 62 technical assistance projects for $\$ 22.45$ million. It has disbursed $\$ 52.2$ million in cumulative disbursements. ${ }^{63}$ Currently there are two active technical assistance projects and four active loans and grant projects.

In 2011, ADB and the World Bank opened the ADBWorld Bank Joint Vanuatu Liaison Office. In 2016, ADB opened an extended mission in Vanuatu, further strengthening ADB's in-country presence. In 2014, ADB conducted a detailed macrolevel political economy analysis of Vanuatu to inform its future operations. The report recommended a thorough understanding of the political and cultural context for more effective development. ${ }^{64}$

\section{Country Operations Business Plan, 2017-2019}

The Vanuatu country operations business plan (COBP) is aligned with the strategic priorities of the Pacific Approach, 2016-2020; the Midterm Review of Strategy 2020; ${ }^{65}$ and the government's Priorities and Action Agenda, 2006-2015, along with Vanuatu's infrastructure strategic investment plan and national energy road map. ${ }^{66}$ The Pacific Approach will assist the 11 smaller Pacific island countries, including Vanuatu, in pursuing opportunities for economic growth, job creation, and human development by reducing costs, managing risks, and enabling value creation.

The 2017-2019 COBP continues the approach of ADB in Vanuatu through support to three sectors: energy, transport, and water and other urban infrastructure and services. Public sector management is a new sector for ADB involvement in the 2017-2019 COBP. Vanuatu will also be included in regional operations on agribusiness and tourism. Private sector development is supported through the Pacific Private Sector Development Initiative and the Pacific Business Investment Facility.

Following Tropical Cyclone Pam, ADB's immediate support to the government included the approval of grant financing from the Asia Pacific Disaster Response Fund. This was followed by the approval of two cyclone recovery projects for roads and schools reconstruction.

\section{ADB-Supported Activities Involving Civil Society}

\section{Supporting the Preparation of the National Sustainable Development Plan}

With Vanuatu's current national development plan, the Priorities and Action Agenda, ending in 2015, the government is in the process of finalizing a new development plan. The government established a core team to lead the preparation of the new national sustainable development plan, along with the Department of Strategic Policy Planning and Aid Coordination. The core team is made up of representatives from the government, civil society, the private sector, academia, and development partners. ADB is providing technical support to assist the government prepare the new national sustainable development plan. ${ }^{67}$

\section{Vanuatu Women's Development Scheme}

The Vanuatu Women's Development Scheme (VANWODS) started as a pilot project implemented under the then Department of Women and Culture in 1996 with financial and technical support from the United Nations Development Programme-United Nations Office for Project Services Regional Equitable and Sustainable Human Development Project. The project was initiated in response to the Vanuatu National Plan of Action for Women to provide disadvantaged women with access to microfinance and income earning opportunities.

VANWODS now operates as the only primary nonbank financial institution to provide microfinance savings and loan services to primarily women outside the urban centers. Since 2008 it has had a ni-Vanuatu management and has grown to service (with loan and savings products) almost 7,200 women through four branches in four provinces (Efate, Espiritu Santo, Malekula, and Tanna). The savings volume reached Vt267 million or \$2.9 million equivalent in May 2015. Loan volumes reached a total of Vt138 million or \$1.27 million equivalent in May 2015. 
ADB has been supporting VANWODS under the Expansion of Rural Financial Services project to upgrade its institutional capacity and governance arrangements. ${ }^{68}$ Following Cyclone Pam, support focused on rebuilding and restoring VANWODS facilities and equipment to enable its operations to continue following the cyclone.

ADB in Vanuatu is involved with the Coral Triangle Initiative Coral Reefs, Fisheries, and Food Security, which was launched in 2007. It is as a multilateral partnership between six Pacific island countries, including Vanuatu. The Coral Triangle Initiative is being implemented in cooperation with the civil society group WWF, and ADB has an MOU in place with WWF to govern these partnership arrangements around natural resource management.

\section{Japan Fund for Poverty Reduction}

The Japan Fund for Poverty Reduction was established in 2000. It provides direct assistance to the poorest and most vulnerable groups in the developing member countries, while fostering long-term social and economic development. ${ }^{69}$ It provides both project grants and technical assistance to developing member countries. Since its establishment in 2000, it has approved nine grants for the Pacific. It has provided one technical assistance to Vanuatu: the State-Owned Enterprise Rationalization Program, approved in 2010 and valued at $\$ 500,000$.

\section{Endnotes}

1 M. Cox et al. 2007. The Unfinished State: Drivers of Change in Vanuatu. Australian Agency for International Development: Canberra.

2 ADB. 2015. Understanding the Political Economy of Vanuatu. Manila.

3 B. Douglas. 2007. Christian custom and the church as structure in 'weak states' in Melanesia. In H. James. Civil Society, Religion and Global Governance: Paradigms of Power and Persuasion. Routledge: London and New York.

4 Footnote 3 .

5 A. McCormick. 2011. Some Partners are More Equal than Others: EFA and Civil Society in Papua New Guinea and Vanuatu Education Policy Processes. International Education Journal. 10 (2), 54.

6 L. Bolton. 1999. Chief Willie Bongmatur Maldo and the Incorporation of Chiefs into the Vanuatu Sate. State Society and Governance in Melanesia Discussion Paper 99/2. Canberra: Australian National University.

7 M. Mohanty. 2011. Informal Social Protection and Social Development in Pacific Island Countries Role of NGOs and Civil Society Asia-Pacific Development Journal. 18 (2) pp. 25-56.

8 Footnote 2.

9 Footnote 6

10 H. Hill. 1994. Theory \& Practice in Pacific NGOs. In W. vom Busch et al. eds. New Politics in the South Pacific. Raratonga and Suva: University of the South Pacific in association with the Pacific Islands Political Studies Association.

11 The Anglican Church of Melanesia. About Mothers Union. http:// www.acom.org.sb/ministries/board-of-mission/mothers-union

12 P. Thomas. 2012. Cluster Evaluation of AusAid Vanuatu Civil Soci- ety and Media Programs. http://dfat.gov.au/about-us/publications/ Documents/vanuatu-media-strengthening-cluster-evaluation.pdf

Footnote 6

14 A. F. P. Faasau. 2004. Report on Laws Affecting Civil Society in Vanuatu 2004. Washington, DC: International Center for Not-forProfit Law.

15 A. Jowitt. 2014. National Integrity System Assessment Vanuatu 2014. Transparency International Vanuatu.

16 List provided by Benjamin Shing, acting director general of the Ministry of Internal Affairs.

17 Footnote 12

18 Footnote 1.

Footnote 1.

20 Footnote 1.

$21 \quad$ L. S. Garcia. 2006. Pacific Skills Link Action Research Project: Understanding Civil Society in Kiribati, Tuvalu, and Vanuatu January 2006. Pacific Skills Link.

22 Global Integrity. Global Integrity Report 2013. Vanuatu. https:// www.globalintegrity.org/research/reports/global-integrity-report/global-integrity-report-2013/gir-scorecard-2013-vanuatu/

23 Footnote 21.

24 Pacific Media Assistance Scheme. 2013. Vanuatu State of Media and Communications Report http://www.pacmas.org/wp-content/ uploads/2013/10/11.-PACMAS_Vanuatu-Country-Report_FINAL. pdf2013

25 Footnote 24.

26 G. Finau et al. 2014. Social Media and e-Democracy in Fiji, Solomons and Vanuatu. Twentieth Americas Conference on Information Systems, Savannah, Georgia.

27 Government of Australia, Department of Foreign Affairs and Trade. 2006. Government of the Republic of Vanuatu Priorities and Action Agenda 2006-2015. https://dfat.gov.au/about-us/publications/Documents/government-of-vanuatu-priorities-action-agenda-2006-15.pdf

28 Footnote 1.

29 Footnote 1.

30 Footnote 15

31 Footnote 15

32 Footnote 1.

33 Government of Australia. 2009. Stop Violence: Responding to violence against women in Melanesia and East Timor. Canberra.

34 P. Thomas. 2012. Cluster Evaluation of AusAid Vanuatu Civil Society and Media Programs. http://dfat.gov.au/about-us/publications/ Documents/vanuatu-media-strengthening-cluster-evaluation.pdf

35 World Bank. 2006. Opportunities to Improve Social Services in Vanuatu: Summary Report. Washington, DC.

36 Footnote 15

37 Live\&Learn. Vanuatu. http://www.livelearn.org/locations/vanuatu

38 Footnote 15

39 Oxfam Australia. 2015. Lessons from the Vanuatu NGO Climate Change Adaptation Program. Melbourne.

40 Footnote 15

$41 \quad$ Pacific Institute of Public Policy. 2009. Planning, Monitoring and Evaluation of Government Systems: A Women and Child Focused Perspective Baseline Diagnosis Kiribati, Solomon Islands and Vanuatu. Port Vila.

42 M. Nichol. 2014. Principles in practice? Ownership in monitoring and Evaluation in Vanuatu. Thesis for Master of Development Studies. Victoria University of Wellington.

43 S. Cowlishaw. 2015. Cyclone Pam: Vanuatu Slams Aid Agencies. Stuff.co.nz. http://www.stuff.co.nz/world/south-pacific/67440364/Vanuatu-slams-aid-agencies; ABC News. 2015. Tropical Cyclone Pam: Vanuatu's government criticizes aid groups over poor coordination of disaster relief. http://www.abc.net.au/ news/2015-03-19/vanuatu-criticises-lack-of-aid-coordination-after-cyclone-pam/6333676 (19 March 2015).

44 Footnotes 12 and 43 .

45 ABC News Pacific Beat. 2015. Vanuatu Council of Women want respect for legal process. 3 November

46 Footnote 14

47 Footnote 14

48 Footnote 15

49 Information from Charlie Harrison, interim chair of the board of VANGO. 
50 Footnote 15

51 Footnote 15.

52 Anglican Board of Mission. Vanuatu Church Partnership Program. http://www.abmission.org/pages/vanuatu-church-partnershipprogram-vcpp.html

53 Footnote 15.

54 Footnote 15.

55 Footnotes 21 and 1.

$56 \quad$ Footnotes 1 and 15.

57 Footnote 21.

58 Footnote 15.

59 Footnote 15.

60 Footnote 15.

61 Footnote 21

62 Footnote 12.

63 Footnote 1.
64 Footnote 2.

65 ADB. 2014. Midterm Review of Strategy 2020: Meeting the Challenges of a Transforming Asia and Pacific. Manila.

66 Government of Vanuatu. 2006. Priorities and Action Agenda 20062015. Port Vila; Government of Vanuatu. 2015. Vanuatu Infrastructure Strategic Investment Plan 2015-2024. Port Vila; Government of Vanuatu. 2013. Vanuatu National Energy Roadmap 2013-2020. Port Vila. The government is currently preparing a new national sustainable development plan covering 2016-2030.

67 ADB. 2014. Technical Assistance to Vanuatu for Supporting the Preparation of the National Sustainable Development Plan. Manila.

68 ADB. 2013. Technical Assistance to Vanuatu for Expansion of Rural Financial Services. Manila.

69 ADB. 2015. Japan Fund for Poverty Reduction Annual Report 2013. Manila.

For more information about ADB's work in Vanuatu, visit www.adb.org/countries/vanuatu/main; www.adb.org/ publications/vanuatu-fact-sheet

\section{Definition and Objectives of Civil Society Collaboration}

Civil society is an important stakeholder in the operations of the Asian Development Bank (ADB) and its borrowers and clients. It is distinct from the government and the private sector and consists of a diverse range of individuals, groups, and nonprofit organizations. They operate around shared interests, purposes, and values with a varying degree of formality and encompass a diverse rangefrom informal unorganized community groups to large international labor union organizations. Of particular relevance to ADB are nongovernment organizations, community-based organizations and people's organizations, foundations, professional associations, research institutes and universities, labor unions, mass organizations, social movements, and coalitions and networks of civil society organizations (CSOs) and umbrella organizations. ${ }^{2}$

ADB recognizes $\mathrm{CSO}$ s as development actors in their own right whose efforts complement those of governments and the private sector, and who play a significant role in development in Asia and the Pacific. ADB has a long tradition of interacting with CSOs in different contexts, through policy- and country strategy-level consultation, and in designing, implementing, and monitoring projects.

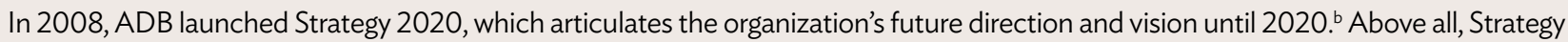
2020 presents three complementary strategic agendas to guide ADB operations: inclusive economic growth, environmentally sustainable growth, and regional integration. These agendas reflect the recognition that it is not only the pace of growth but also the pattern of growth matters in reducing poverty in the region. In this new strategic context, partnerships with a range of organizations, including CSOs, will become central to planning, financing, implementing, and evaluating ADB projects.

a ADB. 2012. Strengthening Participation for Development Results. Manila.

b ADB. 2008. Strategy 2020: The Long-Term Strategic Framework of the Asian Development Bank, 2008-2020. Manila.

In this publication, “\$” refers to US dollars.”

ADB recognizes "China" as the People's Republic of China, and "East Timor" as Timor-Leste.
Pacific Liaison and Coordination Office Level 20, 45 Clarence Street Sydney, NSW Australia 2000

Tel +61282709444

Fax +61282709445

adbplco@adb.org www.adb.org/solomon-islands

Vanuatu Liaison Office Level 5, Reserve Bank Building Rue Emile Mercet P.O. Box 3221 Port Vila, Vanuatu Tel +67823610 Fax +67822636

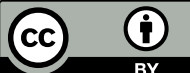

(C) 2017 ADB. The CC license does not apply to non-ADB copyright materials in this publication.

Corrigenda to ADB publications may be found at http://www.adb.org/publications/corrigenda

Publication Stock No. BRF178677

DOI: http://dx.doi.org/10.22617/BRF178677

pubsmarketing@adb.org 